\title{
Dual careers, time-use, and satisfaction levels: evidence from the British Household Panel Survey
}

\author{
Daniel Wheatley and Zhongmin $\mathrm{Wu}^{1}$
}

\begin{abstract}
This paper empirically examines time-use and its impact on satisfaction levels among dual career households in a post-industrial economy, the UK. Analysis explores the 1993-2009 British Household Panel Survey using panel probit regression. The evidence reveals distinctions in time-use relative to gender, occupations, and employment sector. Long hours persist among managers and professionals. The uneven division of household labour, further, continues to burden women with extensive amounts of housework and care. Satisfaction with working hours and amount/use of leisure time are lower among women, especially public sector professionals. Provision of care, occupation, and partner employment characteristics represent important satisfaction determinants present among women, while income (including partner's income) only has relevance among men. Housework does not itself generate dissatisfaction. It is the overload of household tasks, due to inequality in the household division of labour, which constrains many highly skilled working women reducing satisfaction with time-use and life overall.
\end{abstract}

\section{Introduction}

This paper contributes to our understanding of patterns in time-use among dual career households, using empirical evidence from a post-industrial economy, the UK. Specific focus is given to the household division of labour and realized outcomes for partners in respect of reported satisfaction levels. Dual career households differ from dual earner households — those where both partners are in paid work — in that both partners are employed in highly skilled managerial, professional or associate professional occupations (Hakim, 2002; Hardill

\footnotetext{
${ }^{1}$ Nottingham Business School, Nottingham Trent University.
} 
and Wheatley, 2009). Partners in these households both pursue careers, and engage in fulltime paid work for the majority of their adult lives. The distribution of elements of time-use in these households is therefore especially interesting as there is, in principle, no obvious lead and secondary career present. While the term 'career' has traditionally been used to describe long-term progression, a ladder, or linear promotion, within an occupation or series of occupations involving increasing responsibility (Evetts, 2000), careers are increasingly multidirectional, flexible and flat, driven by the needs of the organization and the individual (Baruch, 2004, 68-70). While partners in dual career households both pursue careers this does not, however, suggest that the careers of these men and women are the same. Women have complex careers — referred to as multi-directional (Baruch, 2004), patchwork, boundaryless, or frayed (Peel and Inkson, 2004: 544) — which are distinct from men. The 'typical' female career trajectory is non-linear, complex and dynamic (Peel and Inkson, 2004).

In dual career households combining work (career) and home is likely to be particularly complex. Dual career households do not fit the traditional male-breadwinner, femalehomemaker model of the household. These households have the potential to be egalitarian, but evidence is conflicting in respect to whether these households reflect relative equality in decision-making and the distribution of various forms of work (Hardill and Wheatley, 2009, 239; Philp and Wheatley, 2011). Combining dual careers with the home may require the (short term) prioritization of one partner's career at the expense of the others (Hardill, 2002). Women in dual career households who are mothers have a stronger attachment to the labour market after childbirth than other groups of women (Hardill and Wheatley, 2009). But, greater labour market equality may not equate to an egalitarian distribution of tasks within the home (Garcia et al, 2007). Dual career households are important because of their growing significance as a category of household in post-industrial economies. There have been 
notable increases in managerial and professional occupations relative to other occupations (Goos and Manning, 2007). In the UK dual career households numbered over 1.2 million in 1991. This had increased to 2.23m (10\% of all households) by 2001 (Hardill and Wheatley, 2009, 240), and approximately 12\% (3.19m) of households by 2011 (estimate from Understanding Society, 2012). Increases have been driven by female labour market participation, and polarization into work-rich-time-poor and work-poor-time-rich households (McDowell et al, 2005). A growing sub-set of couples engage in very long working weeks (Cha, 2010, 303), while managers and professionals in particular work some of the longest hours, on average, of all categories of workers in the UK (Philp and Wheatley, 2011). It should, though, be noted that even with higher participation rates, approximately $40 \%$ of women overall in the UK remain in part-time employment (Gregory and Connolly, 2008, F52). However, the specific focus of this paper is households where both partners work fulltime. For these households achieving balance between highly skilled careers and family life is critical, as they face particular difficulties in managing complex routines of paid work and household labour (Wheatley, 2012, 2013; Sandow, 2014, 529). The links between satisfaction levels and the distribution of various activities — forms of time-use — is therefore of key interest in improving our understanding of these households.

This paper aims to empirically examine patterns in time-use among dual career households, and the outcomes for men and women in these households with respect to stated satisfaction levels. Specifically, this paper seeks to answer the following two research questions:

(1) Are distinctions present in time-use within dual career households in respect of gender, occupation, and employment sector, and; 
(2) How does the distribution of labour in dual career households impact satisfaction with (i) working hours, (ii) job overall, (iii) amount of leisure time, and (iv) use of leisure time?

The empirical analysis uses 17 waves of the British Household Panel Survey (BHPS) between 1993 and 2009. The focus is on a post-industrial economy — the UK — thus some findings are representative of the UK case only. Findings, though, have cognizance to other post-industrial societies, including the US and other European nations. The UK presents an interesting empirical focus as it has long been considered to reflect a comparatively liberal stance on employment policy (Lewis and Campbell, 2008), especially when compared with some other European nations, for example those that follow the Nordic welfare model (Arenius and Kovalainen, 2006). However, the UK has, in recent years, implemented a number of formal and informal policies aimed at improving working conditions.

\section{Dual careers, time allocation and satisfaction levels}

Growth in dual career households, and the lengthy working hours found among managers and professionals should be considered in context to the changing policy environment in the UK. Conservative governments adopted liberal supply-side approaches to labour market regulation between 1979 and 1997. The European Working Time Directive (EWTD), passed in November 1993, was initially refused implementation in the UK. The EWTD (Council Directive 93/104/EC) imposes a maximum working week of 48 hours and annual paid leave of at least four weeks, to protect the health and safety of employees (European Commission, 2005). The New Labour government, from 1997, re-introduced a National Minimum Wage and, in 1998, the Working Time Regulations (WTR). This policy offers the leave entitlements and maximum 48 hour working week (averaged over 17 weeks) of the EWTD. However, in contrast to other European economies the WTR included, from inception, a voluntary opt-out 
for employees allowing their working hours to exceed the 48 hour limit (BIS, 2011). Further policy has been implemented in an attempt to increase the flexibility of paid work. The Work-Life Balance Campaign (WLBC), implemented in spring 2000, aimed to raise employers' awareness of the benefits to business and employees from introducing policy and practice to improve work-life balance (BIS, 2011a). Meanwhile, the 2003 Flexible Working Regulations (FWR), last updated in 2009, offer workers the right to request flexible working, albeit these requests can be rejected by employers on grounds of ‘business need’ (BIS, 2011). Gaps between the aims and implementation of this policy (Wheatley, 2012), however, may create and exacerbate work-life conflict among UK dual career households.

\section{Dual career households and household models}

Households can be broadly categorized as, (1) 'traditional' illustrated by the male breadwinner, female homemaker model, (2) 'transitional' characterized by the collective model/adult-worker model family, or (3) 'egalitarian', where an egalitarian household is characterized by, amongst other things, partners sharing housework equally (Hochschild and Machung, 1990). The dual career household does not fit the traditional model of the household. Mainstream approaches in economics, typified by Becker (1976), are founded on a unitary model of the household in which the household is considered a single decisionmaking entity, led by a male 'dictator'.2 Under Becker’s model men and women’s timeinputs to the household are considered perfect substitutes (Lundberg and Pollak, 2007, 12). This results in similar average amounts of residual time, for activities including pure consumption and sleep, by gender. But this mainstream model ignores the potential for exploitation and prioritization, for example the male career taking precedence and

\footnotetext{
${ }^{2}$ Mainstream theory, it should be noted though, does provide conditions under which a non-self-centered approach to decision-making can be modeled using the concept of the family or household.
} 
significantly influencing household decision-making (Cha, 2010). The traditional model is thus increasingly incompatible with social reality (Crompton et al, 2007). The limitations of the 'traditional' model have led to reinterpretation. For example, the collective model regards households as consisting of several individuals with their own rational preferences (Browning and Chiappori, 1998), with decisions made resulting in Pareto efficient outcomes (Vermeulen, 2002; Garcia et al, 2011, 121). Game theoretic models have also attempted to explain decision-making within households (van Staveren, 2010, 1129). These include both bargaining models and consensual models, which acknowledge that households are multiperson and that decisions are made by individuals with their own preferences and constraints (Grossbard, 2010). A commonality among these models is that they suppose a degree of 'jointness' in decision-making. These approaches, however, cannot easily explain the contradicting gender norms that influence households. For example, women's role as primary carer does not perfectly reflect assumptions of self-interest (van Staveren, 2010, 1129).

Dual career households may follow more closely the 'adult-worker model family' as defined by Lewis (2001, 154). This model is characterized by all adults within a household engaging in the labour market. However, much of the discussion in Lewis (2001) is concerned with 'one and a half worker' (or dual earner) households where one partner is engaged in full-time paid employment while the other, often the female, is engaged in part-time work for at least part of their career (Lewis, 2001, 155). In the past, women often took career breaks to have children. However, this trend has decreased in recent years as more women remain in fulltime employment. This trend is also driven, in part, in the UK by government employment and welfare policies which encourage employment among mothers (Lewis and Campbell, 2008, 535-6). Women remain in employment by making use of both market and non-market, family-based, care (Harris et al, 2007). In dual career households both partners more often 
remain engaged in full-time employment. Moreover, women in the UK have in recent years become increasingly likely to be the household's primary earner (Soobedar, 2011), hence there should increasingly be no lead career within these households. Women in dual career households most closely represent 'work-centred' women, as defined in Hakim's (2002) preference theory. Even within this group, though, there are nuanced variations and contradictions, which render Hakim’s categorization unsuitable (Lewis and Campbell, 2008). Recent empirical research by Livingston (2011, 21) is indicative of men and women experiencing household decision-making differently. A bargaining process occurs, including negotiation regarding the household division of labour (Bowles and McGinn, 2008) and the prioritization of career (Livingston, 2011, 2). Gendered expectations, though, impact outcomes for women who are perceived negatively if they 'competitively' pursue career. Women may therefore more often 'accept' the role of secondary career within the household.

Dual career households have the potential to be egalitarian as both partners invest in cultural and symbolic capital (of which education is a significant component), and have a deep commitment to the labour market (Hardill and Wheatley, 2009, 239). However, while decisions over paid work follow a more egalitarian model, the tasks of social reproduction remain a largely female preserve (Hardill, 2002). Importantly, commitment to the labour market does not substantially alter the number of household tasks women perform. Nor does it result in a significant redistribution of household labour between men and women commensurate with their paid labour (Garcia et al, 2007, 2011). Recent UK-based qualitative research is consistent with this assertion: younger couples, while in principle supporting equality, often do not evidence an egalitarian distribution of household labour. Meanwhile, older couples reported housework as a predominantly female activity (van Hooff, 2011, 267). The benefits of flexible working may thus be especially important to working mothers 
(Dikkers et al, 2010, 576). The uneven allocation of household tasks reinforces fundamental inequalities in economic power between male and female partners (Hardill and Watson, 2004, 21), and may result in real difficulties in achieving balance between work and life if women are to avoid negative career implications associated with extensive use of flexible working arrangements (Atkinson and Hall, 2009, 663). The economic lives of men and women have converged in the past 50 years, however important divisions persist within the household (Lundberg and Pollak, 2007, 6-7). Empirical evidence suggests that, even within dual career households, gender inequality in decision-making and time-use remain present (Wheatley, 2013). Some degree of both conflict and compromise persist.

\section{Time-use and satisfaction levels}

Women still undertake the bulk of unpaid work in most households (Garcia et al, 2007, 2011). Evidence has pointed toward some improvement in the gendered distribution of labour (see Sullivan, 2010). For example, men often chauffeur their children (Schwanen, 2007). However, women continue to undertake the majority of housework, as well as acting as primary care givers (Garcia et al, 2011). Their labour market participation does not simply reflect labour supply preferences, but instead their culturally assigned role of unpaid worker in the household. This is evident in that women remain more likely than their male counterparts to quit their job where their partner is overworked (works long hours). Gendered expectations result in women's careers, even in managerial and professional occupations, taking on a secondary role especially where dependent children are present (Cha, 2010, 31920). Even in post-industrial economies praised for their family friendly working policies, including Sweden and other Scandinavian countries, gender pay gaps and career implications reflect a less than ideal outcome for many women (Hakim, 2004). Inequalities remain in the home, and at work. This is despite increasing numbers of women participating and remaining 
in the labour force for the majority of their adult lives, and changes in the nature and occupational structures of work (Perrons et al, 2005). Women that are married/co-habiting and have dependent children often incur a 'double-shift' of paid work outside the home and unpaid work inside the home (Jones, 2003, 7). Flexible working arrangements or work-family policies, including part-time and homeworking, can be used to successfully manage home and work. However, this can limit career opportunities and impair wage growth among mothers, especially in managerial and professional occupations (Glass, 2004, 387). Increasing financial, social and political pressure is felt by households for both partners to remain in some form of paid employment.

The occupation and employment sectors in which careerists engage are central to our understanding of these households. Partners in dual career households work in managerial, professional, and associate professional occupations. It has been shown empirically that, in the UK, managers and professionals are the categories of workers who work the longest hours (Philp and Wheatley, 2011). This pattern is also evident in a number of EU economies, including Germany and France (Philp and Wheatley, 2013). However, these occupation groups are themselves distinct. Some scholars have attempted to group these occupations. For example, Ehrenreich and Ehrenreich (1979) argued the development of a professionalmanagerial class (PMC), while Goldthorpe (1995) described these workers as constituting a 'service class'. However, there remains conflict and distinction between those in 'managerial roles' and those in 'service professions' and between 'private sector business' and 'non-profit agencies' (Wheatley et al, 2011, 412). Managerial occupations increasingly have a range of different grades reflecting levels of seniority and responsibility. Professional roles, further, often possess some managerial duties. However, the role of managers is one of the imposition of work onto others. Managers represent the interests of their organization, and key to their 
role is a supervisory function (Gordon, 1996, 40), often requiring lengthy hours and visible presence within the organization. Moreover, recent research suggests that within the public sector, the presence of work-life balance policies have not reduced the working hours of managers due to pressure of workloads. Instead they use flexibility to 'fit in' family and leisure, but continue to work longer hours (Ford and Collinson, 2011, 267). In contrast professionals are characterized by greater autonomy, although expansion in recent years especially in the private sector, has led to some blurring and ambiguity regarding the nature of professional occupations (Wheatley et al, 2011, 413). This paper seeks to consider to what extent these conceptual distinctions are manifest in respect to empirical differences in timeuse and reported satisfaction levels.

The extant literature identifies a range of determinants of satisfaction levels (see Dolan et al, 2008 for a discussion of these). Of specific interest in this paper, though, are those pertaining to time-use and the household division of labour, occupation, and gender. With respect to time-use, long working hours (including overtime) have been identified as reducing satisfaction among highly skilled workers (Wheatley et al, 2011). However, notable differences have been found present between managers and professionals: managers’ report a lesser preference for reductions in hours (Philp and Wheatley, 2011). This is evident of the distinct nature of these occupations and those individuals who undertaken them. Occupation and income have been identified as central drivers of the satisfaction levels of men (Della Giusta et al, 2011, 22). In respect to other aspects of time-use, lengthier commutes have been identified as reducing 'life' satisfaction (Stutzer and Frey, 2008). Meanwhile, women in particular report dissatisfaction with the hours of paid work, as they are constrained by household and caring responsibilities. The presence of dependent children creates added complexity for women as they attempt to combine work and life, reducing satisfaction with 
leisure (Garcia et al, 2007). Lengthy hours of care (adult and child) have also been shown empirically, using panel data from the BHPS, to have negative impacts on satisfaction with life overall among women (Della Giusta et al, 2011, 17-18). Although not focusing on dual career households this research is evident of the continued presence of gender norms in the allocation of household time. This aligns with MacDonald et al's (2005) findings, using Canadian data, which identify that the household division of labour generates stress among women as they attempt to combine paid work with lengthy hours of unpaid work.

Flexibility thus continues to be integral for many women (Wight and Raley, 2009), but flexible working arrangements may not deliver desired benefits. For example, while women working part-time report higher levels of satisfaction (Gregory and Connolly, 2008), they also report performing more hours of housework than other women (Wight and Raley, 2009). In addition, use of flexible working arrangements can result in reductions in job quality, identified as a potentially important factor in determining relative job satisfaction (Brown et al, 2012). Other research suggests that women may actually report higher levels of job satisfaction than men. Hodson (2005) suggests this, though, may reflect that women compare their relative satisfaction on a lesser scale and/or that women are less willing to communicate their dissatisfaction regarding work. Women's job satisfaction remains more likely to be negatively influenced (than their male counterparts) by conflicts between work and life, as a result of the greater propensity for them to become 'overloaded' by their household contribution (Ergeneli et al, 2010, 692). The predominance of full-time working hours in dual career households may combine to exacerbate the challenges for women attempting to effectively balance career with life. Broader evidence reflecting on the determinants of satisfaction levels, further, suggests that a focus on career can produce lower levels of satisfaction (Headey, 2008). The impact of the pursuit of dual careers on the household 
division of labour, and reported satisfaction levels, is therefore of specific interest to our understanding of dual career households.

\section{Data and Methods}

Time-use among men and women in dual career households is explored in this paper using the British Household Panel Survey (BHPS), 1993-2009 (17 waves). ${ }^{3}$ The BHPS allows for longitudinal analysis of men and women workers. It provides data collected from households on a year-on-year basis reflecting on various aspects of time-use and satisfaction. The BHPS was designed using a stratified random sampling method as an annual survey of each adult member (aged 16 years and over) of a nationally representative sample of over 5,000 households (10,000 individuals). Since 1992 individuals have been successively reinterviewed and, if they leave their original households, all adult members of their new household are interviewed. Children are interviewed once they reach 16 years of age (BHPS, 2009). The BHPS provides a sample of between 716 (1993) and 1,312 (2009) full-time workers in dual career households, where dual career households are defined as households where both partners are employed in a managerial, professional, or associate professional occupation (using Major Occupation Groups from the UK Standard Occupational Classification). Using this data allows analysis of a range of elements of weekly time-use. Work-time is used to describe the time spent in work for an employer (working hours; overtime (paid and unpaid)). Commuting time (in hours) is a necessary work-related activity, but is distinct from work-time. Household time describes time in other work activity

\footnotetext{
${ }^{3}$ The data (and tabulations) used in this (publication) were made available through the ESDS Data Archive. The data were originally collected by the ESDS Research Centre on Micro-Social Change at the University of Essex (now incorporated within the Institute for Social and Economic Research). Neither the original collectors of the data, nor the Archive, bear any responsibility for the analyses or interpretations presented here.
} 
including housework, and (ill/elderly) care. ${ }^{4}$ Importantly, as this paper reflects on the household division of labour, housework hours per week are collected in the BHPS unlike a number of other surveys e.g. UK Labour Force Survey. Housework hours were not collected in 1992, though, thus data from 1993 until 2009 is presented in this paper. To provide an indication of the type of housework being performed by partners, responses to questions considering who is mainly responsible for the completion of cleaning, ironing, shopping, and cooking, are also included in the analysis. The number of hours spent caring for dependent children is not collected in the BHPS. Instead the analysis considers responses to the question, 'Who is mainly responsible for looking after the child(ren)?'5

Descriptive analysis is developed using ordered probit panel regression analysis. Application of regression analysis to the exploration of time-use using panel data is consistent with that of other recent research, including Della Giusta et al (2011) and Garcia et al (2011). It further builds upon Philp and Wheatley (2011) which uses logistic regression analysis of crosssectional data extracted from the BHPS. The ordered probit regression techniques used in this paper provide the most robust method of analysis due to the discrete 'choice' nature of the dependent variables. Satisfaction with (1) working hours; (2) job overall; (3) amount of leisure time, and; (4) use of leisure time are the dependent variables. These stated preference variables summarize the results of questions included in the BHPS which capture how

\footnotetext{
${ }^{4}$ Commuting hours is derived from responses to the question, 'About how much time does it usually take for you to get to work each day, door to door?' Caring hours appears in categorized format in the BHPS and is therefore analyzed in this form. Table 1 summarizes averages for care derived from the median of each interval. ${ }^{5}$ It should be acknowledged that the question on housework hours per week included in the BHPS could underestimate men's contribution to some extent as it is asked in reference to typical household tasks more often performed by women. The variables considering who is responsible for certain household tasks and childcare were only included in the BHPS from 1995. Responses to these questions are as follows: (1) mostly self; (2) mostly partner, (3) shared, and; (4) paid help.
} 
individuals feel about specific aspects of their lives. They are asked on a Likert scale from 1 (dissatisfied) to 7 (satisfied) following the seven 'delighted to terrible' categories (see Angner, 2010). The dependent variables are regressed against a range of time-use, employment, demographic, and partner characteristics. These variables include those of specific focus to this research, and a range of controls identified as relevant in the extant literature (see Dolan et al, 2008). Analysis of partner characteristics is included to provide evidence of the impacts on satisfaction levels of the intra-household division of labour.

\section{Empirical analysis: British Household Panel Survey 1993-2009}

Analysis of the BHPS data, summarized in Table 1, is indicative of employer-related timeuse being longer, overall, among men. ${ }^{6}$ Full-time working hours, and hours of overtime, are lengthier among men in managerial and professional occupations. However, there remain some notable exceptions. For example, mean hours of overtime reported among public sector professional women are particularly long. They are the longest of any occupation group, varying between seven and nine hours per week between 1993 and 2009. It should be noted, though, that during the sample period some decline is recorded in work-time among partners of dual career households. For example, men in full-time private sector managerial roles report a decline from around 43 hours per week to 41 hours per week. This is similarly evident among female private sector managers (reduction of four hours per week). However, although showing some decline, hours do remain long consistent with the findings of other research (Philp and Wheatley, 2011; Ford and Collinson, 2011). Moreover, work-time in

\footnotetext{
${ }^{6}$ ANOVA tests confirm that the patterns among men and women by occupation group (interaction) observed in annual mean hours in Figure 1 and 2 - mean working hours $(F=2.77$, S.E. $=1.510$, p-value 0.019), overtime $(\mathrm{F}=5.33$, S. E. $=1.367$, p-value 0.000), commutes $(\mathrm{F}=2.50$, S.E. $=0.611$, p-value 0.032), housework $(\mathrm{F}=$ 4.21, S.E. $=1.125$, p-value 0.001), and care $(F=4.41$, S.E. $=0.825$, p-value 0.001$)-$ are statistically significant, and as such are representative of the wider population.
} 
certain occupation groups, private sector managers in particular, continues to exceed the WTR maximum. There are also some important exceptions to the trend of declining hours. In associate professional roles, the hours of full-time private sector men remained relatively static between 1993 and 2009 at 39 hours per week. This in itself represents an important finding as some occupation groups actually report little change over the 17 year period.

\begin{tabular}{|c|c|c|c|c|c|c|c|c|}
\hline & Occupation & Sector & Hours & Overtime & Commute & Housework & $\begin{array}{l}\text { Care (ill or } \\
\text { elderly) }\end{array}$ & $\mathrm{n}$ \\
\hline \multirow[t]{6}{*}{ Male } & \multirow{2}{*}{$\begin{array}{l}\text { Managers and senior } \\
\text { officials }\end{array}$} & Private & 42.1 & 7.3 & 5.4 & 4.5 & 0.5 & 163 \\
\hline & & Public & 40.3 & 5.5 & 6.0 & 5.7 & 1.8 & 33 \\
\hline & \multirow[t]{2}{*}{ Professionals } & Private & 38.7 & 5.6 & 5.8 & 4.5 & 0.4 & 80 \\
\hline & & Public & 39.5 & 6.5 & 4.7 & 6.4 & 0.8 & 79 \\
\hline & \multirow{2}{*}{$\begin{array}{l}\text { Associate professional } \\
\text { and technical }\end{array}$} & Private & 38.9 & 4.1 & 5.5 & 4.6 & 0.5 & 93 \\
\hline & & Public & 38.1 & 2.8 & 5.1 & 6.2 & 0.8 & 73 \\
\hline \multirow[t]{6}{*}{ Female } & \multirow{2}{*}{$\begin{array}{l}\text { Managers and senior } \\
\text { officials }\end{array}$} & Private & 39.8 & 5.5 & 5.4 & 9.3 & 0.6 & 88 \\
\hline & & Public & 36.5 & 4.1 & 5.0 & 11.1 & 0.8 & 38 \\
\hline & \multirow[t]{2}{*}{ Professionals } & Private & 37.7 & 5.7 & 5.1 & 8.1 & 0.3 & 52 \\
\hline & & Public & 37.6 & 8.5 & 4.1 & 9.9 & 1.2 & 154 \\
\hline & \multirow{2}{*}{$\begin{array}{l}\text { Associate professional } \\
\text { and technical }\end{array}$} & Private & 37.3 & 3.9 & 4.9 & 9.5 & 1.0 & 74 \\
\hline & & Public & 36.9 & 2.8 & 4.2 & 10.6 & 0.9 & 128 \\
\hline
\end{tabular}

Source: British Household Panel Survey, 1993-2009.

Notes: Data is for full-time employees aged 16-65. Figures (including n values) are averages taken over sample period (17 observations).

Table 1: Weekly time-use among men and women in dual career households, BHPS 1993-2009

Commutes act as an important additional time constraint. Commutes are longer among men in all occupation groups (averaging approximately 5.4 hours per week). In contrast, women commute, on average, 4.8 hours per week. However, the commute does not represent as significant a constraint for men as household time appears to among women. Women's household time is distinctly greater, suggesting a less than egalitarian division of household labour. Hours of housework average 9.8 hours per week among full-time career women; almost double that of men (5.3 hours). Responses to questions regarding who mainly performs household tasks are consistent with this gender imbalance. On average during the sample period, significant proportions of women identified themselves as undertaking the 
majority of these tasks (cleaning (57.8\%), ironing (53\%), shopping (46.7\%) and cooking (53.4\%)), but only around $11.2 \%$ of men, on average, reported themselves as performing the bulk of these tasks with shopping the most common. Remaining couples (about a third overall) reported these household tasks as being shared equally, while it should also be noted that some dual career households utilize marketized provision of both cleaning (around 1.6\% of households) and cooking (7.3\%). Meanwhile, the reported hours of (ill/elderly) care are also longer for women than for their male counterparts, with male public sector managers offering the only exception (see Table 1). Lengthy household time is particularly severe for women professionals (and associate professionals). On average, between 1993-2009 women working full-time in public sector professional occupations, although reporting shorter working hours (37.6 hours per week) than their male counterparts (39.5 hours per week), report lengthy hours of overtime (8.5 hours), housework (9.9 hours), and some of the longest average reported hours of (ill/elderly) care (1.2 hours). This reported time-use does not include the additional burden of hours spent caring for dependent children, which would further impact the time-use of these women. Child care responsibilities are sometimes divided between partners, but often are not (Hardill, 2002). The BHPS data confirms this trend is present among UK dual career households with significant gender divisions present in the provision of childcare. On average during the sample period $56.7 \%$ of women careerists reported they were the primary care provider, compared to just $3.8 \%$ of men (remaining couples report care being shared).

Overall time-use among public sector professional women has remained relatively static and lengthy between 1993 and 2009. This is a particular concern as some women's patterns of time-use render current policy ineffective in directly influencing and driving change. Where work-time is shorter this may seem acceptable. However, other aspects of time-use create 
particular constraint for some partners in dual career households, notably public sector professional women. These women report an average drop in working hours of two hours per week. However, they report very little change in overall time-use, which remained around 60 hours. This is driven by lengthier hours of housework, commuting, and (ill/elderly) care. The additional burden of childcare, shown to be a source of dissatisfaction (Della Giusta et al, 2011; Garcia et al, 2007), thus renders this uneven distribution of household time a considerable concern.

\begin{tabular}{lll|rrrr|l}
\hline & & \multicolumn{5}{c}{ Satisfaction with ... (\%) } \\
& Occupation & Sector & Hours & Job & Leisure time & Leisure use & $\mathrm{n}$ \\
\hline Male & Managers and senior officials & Private & 66.4 & 74.8 & 47.1 & 62.5 & 170 \\
& & Public & 67.6 & 72.0 & 46.8 & 60.4 & 32 \\
& \multirow{2}{*}{ Professional } & Private & 69.0 & 71.8 & 47.8 & 66.8 & 91 \\
& & Public & 70.9 & 77.6 & 49.6 & 60.1 & 78 \\
& \multirow{3}{*}{ Associate prof. and technical } & Private & 72.3 & 71.7 & 53.6 & 63.3 & 95 \\
& & Public & 75.8 & 69.8 & 56.7 & 63.0 & 68 \\
\hline \multirow{2}{*}{ Female } & Managers and senior officials & Private & 65.1 & 73.9 & 42.4 & 58.2 & 84 \\
& & Public & 79.7 & 79.2 & 48.0 & 58.4 & 30 \\
& \multirow{2}{*}{ Professionals } & Private & 66.8 & 68.7 & 46.8 & 62.2 & 37 \\
& & Public & 61.1 & 76.2 & 43.5 & 57.1 & 132 \\
& \multirow{2}{*}{ Associate prof. and technical } & Private & 74.4 & 70.6 & 49.4 & 62.5 & 62 \\
& & Public & 73.3 & 76.0 & 50.2 & 60.5 & 95 \\
\hline
\end{tabular}

Source: British Household Panel Survey, 1993-2009.

Notes: Data is for full-time employees aged 16-65. Figures (including $n$ values) are averages taken over sample period with exception of 2002 when no satisfaction data was included in BHPS (16 observations). Figures for satisfaction with amount and use of leisure time, are averages over 12 years only (questions not included in earlier surveys).

Table 2: Satisfaction levels, BHPS 1993-2009

The BHPS explicitly asks individuals about various aspects of satisfaction. Reported satisfaction with working hours, job overall, and amount and use of leisure time, is summarized in Table $2 .^{7}$ During the sample period women public sector professionals report

\footnotetext{
${ }^{7}$ Results in Table 2 are summarized for all those responding positively i.e. 5-7 on the Likert scale. ANOVA tests confirm that the patterns among men and women by occupation/employment sector (interaction) observed in satisfaction with hours $(F=5.87$, p-value 0.004) and job $(F=6.02$, p-value 0.015) are statistically significant. Proportions stating satisfaction with the amount of leisure time $(F=0.64, p$-value 0.527$)$, use of leisure time ( $F$
} 
the lowest levels of satisfaction with hours (61.1\%). This corresponds closely with the extensive time-use in this occupation group identified in Table 1. In contrast satisfaction with job overall is actually greatest among public sector professional women (76.2\%) and men (77.6\%), and women public sector managers (79.2\%). In the latter case this could be, at least in part, due to the shorter work-time associated with this occupation group. However, for professionals this is indicative of workers gaining satisfaction from their employment in spite of lengthy working hours which themselves create dissatisfaction. This may reflect the impact of the 'quality' of work in determining relative satisfaction in these occupations as suggested in Brown et al (2012). The lowest levels of satisfaction with amount of leisure time are found among women in private sector managerial (42.4\%) and public sector professional (43.5\%) occupations. In both cases this is likely to be driven by the extensive overall timeuse reported, although the distribution of this time is distinct in respect to lengthier commutes among private sector managers and lengthier overtime, housework and care among public sector professionals. Those in associate professional occupations, generally, report greater levels of satisfaction with leisure, likely reflecting their shorter overall time-use (see Table 1). Also important to note is that satisfaction with leisure is generally lower among women, suggesting an inherent gender division in satisfaction with leisure within dual career households. Given the relatively shorter hours of work-time reported among women, on average, this suggests it is other aspects of time-use that are driving dissatisfaction.

\section{Ordered Probit Analysis}

The ordered probit analysis explores this apparent dissatisfaction in more detail. The results of the regression analysis, summarized in Table 3 and 4, suggest important distinctions in the

$=0.20$, p-value 0.821) are, however, statistically insignificant casting some doubt over the reliability of the differences observed. 
drivers of satisfaction levels between men and women, as well as a number of consistencies. Firstly considering demographic characteristics, age and age $2 / 100$ are indicative of a nonlinear relationship between age and satisfaction levels among both men and women, as those who are 'middle aged' report lower levels of satisfaction. This finding is consistent with the extant literature (see Blanchflower and Oswald, 2008). Being married does not reduce satisfaction levels. Satisfaction during 'middle age' is therefore more likely to relate, amongst other factors, to the greater propensity for dependent children at this age which the analysis suggests (consistent with Garcia et al, 2007) reduces levels of satisfaction with amount and use of leisure.

Women in managerial and professional occupations, report lower levels of satisfaction (than associate professionals) in all measures analysed, consistent with them encountering difficulties in managing career and the home. The results pertaining to education are rather mixed, as per the results present in the extant literature (see Dolan et al, 2008). Among women the most highly qualified are less satisfied in respect to leisure. Meanwhile, education among both men and women is positively associated with satisfaction with hours and job. The impact of occupation is further evident as women, with partners in managerial occupations in particular, are less satisfied with their working hours and job. This offers some indication of the impact of male partners working routines in constraining and determining the time-use of women partners in dual career households. Interestingly, those in the public sector report greater levels of satisfaction with hours and job. It is possible that this finding reflects the greater availability of flexible working arrangements in this sector, which although not reducing work-time, does create added flexibility. Those working in the public sector, however, do not report greater satisfaction with leisure. This may be indicative of the impact of extensive overtime and household time (as identified in Table 1) which reduces 
available leisure time among these workers. Finally, consistent with Della Giusta et al (2011) income represents an important aspect of satisfaction among men, but this result is not present among women. Men, further, are likely to report greater levels of satisfaction with leisure as a response to not only their own income, but also their partners, probably reflecting the availability of greater disposable income within the household. These findings may be indicative of men taking on the lead career when children are present in the household, perhaps creating financial compunction (see Philp and Wheatley, 2011). However, this could also reflect a more mercenary attitude toward life among male careerists.

\begin{tabular}{|c|c|c|c|c|}
\hline & \multicolumn{4}{|c|}{ Ordered probit panel regression models (men) } \\
\hline & \multicolumn{4}{|c|}{ Parameter estimates } \\
\hline & \multicolumn{4}{|c|}{ Satisfaction with ... } \\
\hline & Hours & Job & Leisure time & Leisure use \\
\hline Working hours & $.012 * * *$ & $.030 * * *$ & $-.002 *$ & -.001 \\
\hline Overtime hours & $-.028 * * *$ & $.024 * * *$ & $-.019 * * *$ & $-.005^{* * *}$ \\
\hline Commute & $.001 * * *$ & $.002 * * *$ & $-.002 * * *$ & .000 \\
\hline Housework hours & $.015^{* * *}$ & $.007 * * *$ & $.010 * * *$ & .003 \\
\hline \multicolumn{5}{|c|}{ Caring hours: reference is $0-4$ hours } \\
\hline Caring hours 5-19 & -.045 & .055 & -.021 & .027 \\
\hline Caring hours 20+ & -.066 & -.047 & -.025 & -.055 \\
\hline \multicolumn{5}{|c|}{ Major occupation group: reference is associate professional and technical } \\
\hline Managers & $-.119 * * *$ & -.028 & $-.131^{* * *}$ & .006 \\
\hline Professionals & -.021 & .012 & -.010 & .046 \\
\hline Public sector & $.274^{* * *}$ & $.097 * * *$ & $.168 * * *$ & .062 \\
\hline Annual income & $.002 * * *$ & $.002 * * *$ & $.001^{* *}$ & .001 \\
\hline Age & $-.053 * * *$ & $-.040 * * *$ & $-.061 * * *$ & $-.052 * * *$ \\
\hline $\mathrm{Age}^{2} / 100$ & $.056 * * *$ & $.045 * * *$ & $.075 * * *$ & $.063 * * *$ \\
\hline Married & -.012 & .032 & $-.079 * *$ & -.043 \\
\hline No. of children & $.029 * *$ & $.035 * * *$ & $-.119 * * *$ & $-.093 * * *$ \\
\hline \multicolumn{5}{|c|}{ Level of education: reference is no qualifications } \\
\hline Higher degree & $.258^{* * *}$ & $.484^{* * *}$ & -.085 & -.016 \\
\hline First degree & $.141^{* * *}$ & $.378 * * *$ & -.042 & .014 \\
\hline Other higher & $.095 * * *$ & $.203^{* * *}$ & -.001 & .055 \\
\hline A level & $.263 * * *$ & $.414 * * *$ & $.130 * *$ & $.186 * * *$ \\
\hline GCSE/'O’' level & $.202 * * *$ & $.423 * * *$ & -.016 & $.212 * * *$ \\
\hline \multicolumn{5}{|c|}{ Partner characteristics } \\
\hline Partner’s hours & -.001 & .000 & $-.002 * *$ & -.000 \\
\hline Partners' income & .000 & -.000 & $.001^{* *}$ & .000 \\
\hline Partner manager & $-.070 * *$ & -.048 & $-.078 *$ & -.037 \\
\hline Partner prof. & -.067 & $-.127 * * *$ & -.032 & -.042 \\
\hline Partner assoc. prof. & -.048 & $-.092 * *$ & -.068 & -.010 \\
\hline Model Diagnostics: & Log Likelihood = & Log Likelihood = - & Log Likelihood = & Log Likelihood = \\
\hline
\end{tabular}




\begin{tabular}{llll}
\hline$-30,167.14$ & $27,388.50$ & $-23,507.995$ & $-22,674.497$ \\
No. Of Obs. $=$ & No. Of Obs. $=$ & No. Of Obs. $=$ & No. Of Obs. $=$ \\
20,817 & 20,817 & 15,197 & 15,197 \\
LR $X^{2}=965.55$ & LR X $X^{2}=2523.33$ & LR X $X^{2} 438.49$ & LR X $^{2}=160.61$ \\
Prob. 0.000 & Prob. 0.000 & Prob. 0.000 & Prob. 0.000 \\
\hline
\end{tabular}

Source: British household panel survey, 1993-2009 (satisfaction with hours, job), 1997-2009 (satisfaction with leisure amount, leisure use).

Notes: ***, **, * respectively refer to p-values less than 1 percent, 5 percent and 10 percent. Data is for full-time working individuals aged 16-65 in managerial, professional, and associate professional occupations (SOC).

Table 3: Ordered probit panel regression models: satisfaction levels for men (BHPS)

\begin{tabular}{|c|c|c|c|c|}
\hline & \multicolumn{4}{|c|}{ Ordered probit panel regression models (women) } \\
\hline & \multicolumn{4}{|c|}{ Parameter estimates } \\
\hline & \multicolumn{4}{|c|}{ Satisfaction with ... } \\
\hline & Hours & Job & \multirow{2}{*}{$\frac{\text { Leisure time }}{-007^{* * *}}$} & Leisure use \\
\hline Working hours & $.006^{* * *}$ & $.028^{* * *}$ & & -.002 \\
\hline Overtime hours & $-.037 * * *$ & $.014^{* * *}$ & $-.019 * * *$ & $-.006 * * *$ \\
\hline Commute & $.004 * * *$ & $.003^{* * *}$ & -.001 & $.001 *$ \\
\hline Housework hours & $.008^{* * *}$ & $.013^{* * *}$ & .001 & .004 \\
\hline \multicolumn{5}{|c|}{ Caring hours: reference is $0-4$ hours } \\
\hline Caring hours 5-19 & $.105^{* *}$ & $.132 * * *$ & .069 & -.067 \\
\hline Caring hours 20+ & .021 & .068 & $-.185^{*}$ & $-.187^{*}$ \\
\hline \multicolumn{5}{|c|}{ Major occupation group: reference is associate professional and technical } \\
\hline Managers & $-.152 * * *$ & $-.106 * * *$ & $-.105^{* * *}$ & $-.071 * *$ \\
\hline Professionals & $-.168 * * *$ & -.059 & $-.077 * *$ & -.033 \\
\hline Public sector & $.087 * * *$ & $.036 * * *$ & .052 & -.008 \\
\hline Annual income & .000 & $-.001 * *$ & -.000 & -.000 \\
\hline Age & $-.037 * * *$ & $-.036 * * *$ & $-.054 * * *$ & $-.063 * * *$ \\
\hline $\mathrm{Age}^{2} / 100$ & $.030 * *$ & $.037 * * *$ & $.054 * * *$ & $.070^{* * *}$ \\
\hline Married & -.023 & $.085^{* *}$ & $.084 * *$ & .051 \\
\hline No. of children & .008 & $.075^{* * *}$ & $-.221 * * *$ & $-.182^{* * *}$ \\
\hline \multicolumn{5}{|c|}{ Level of education: reference is no qualifications } \\
\hline Higher degree & .004 & $.141^{*}$ & -.018 & .018 \\
\hline First degree & .054 & $.184^{* *}$ & .010 & $.100 *$ \\
\hline Other higher & .025 & $.063^{*}$ & -.033 & -.018 \\
\hline A level & $.145^{* * *}$ & $.281^{* * *}$ & $.106^{* *}$ & .104 \\
\hline GCSE/’O’ level & $.194^{* * *}$ & $.358^{* * *}$ & $.170^{* * *}$ & $.133^{* *}$ \\
\hline \multicolumn{5}{|c|}{ Partner characteristics } \\
\hline Partner’s hours & $.001^{*}$ & .001 & $-.004 * * *$ & $-.003 * * *$ \\
\hline Partners' income & -.000 & .000 & .000 & .000 \\
\hline Partner manager & $-.095 * *$ & $-.110 * * *$ & .019 & .047 \\
\hline Partner prof. & $-.094 * *$ & -.017 & -.009 & .049 \\
\hline Partner assoc. prof. & $-.179 * * *$ & $-.130 * * *$ & $-.110 * *$ & -.040 \\
\hline Model Diagnostics: & $\begin{array}{l}\text { Log Likelihood = } \\
-22,478.92 \\
\text { No. Of Obs. }= \\
14,651 \\
\text { LR X }^{2}=742.03\end{array}$ & $\begin{array}{l}\text { Log Likelihood = } \\
-20,160.18 \\
\text { No. Of Obs. = } \\
14,651 \\
\text { LR X }^{2}=958.39\end{array}$ & $\begin{array}{l}\text { Log Likelihood = } \\
-17,529.284 \\
\text { No. Of Obs. }= \\
10,961 \\
\text { LR X }^{2}=363.63\end{array}$ & $\begin{array}{l}\text { Log Likelihood = } \\
-17,226.319 \\
\text { No. Of Obs. }= \\
10,961 \\
\text { LR X } X^{2}=198.19\end{array}$ \\
\hline
\end{tabular}




\begin{tabular}{l} 
Prob. $0.000 \quad$ Prob. $0.000 \quad$ Prob. 0.000 \\
\hline Source: British household panel survey, 1993-2009 (satisfaction with hours, job), 1997-2009 (satisfaction \\
with leisure amount, leisure use). \\
Notes: ***, **,* respectively refer to p-values less than 1 percent, 5 percent and 10 percent. Data is for \\
full-time working individuals aged 16-65 in managerial, professional, and associate professional \\
occupations (SOC).
\end{tabular}

Table 4: Ordered probit panel regression models: satisfaction levels for women (BHPS)

In respect to time-use, lengthier working hours and overtime have significant negative impacts on satisfaction with the amount and use of leisure time among women. Meanwhile, overtime is associated with dissatisfaction with working hours among both men and women. Interestingly, though, this finding is not present when considering satisfaction with job. This is indicative of workers gaining enjoyment from their job in spite of lengthy work-time (Hodson, 2005). Among women, partners working hours are associated with dissatisfaction with leisure. This is indicative of the greater burden this puts on women with regard to their time, arising from an uneven household division of labour, where both partners work fulltime. Interestingly, the results also suggest that satisfaction with hours is reduced among women by partner's employment. However, this is only present among men where their partner is employed in a managerial occupation, likely reflecting the impact on the household of the extensive hours worked in these roles. Extending the findings of other research (see Stutzer and Frey, 2008), the results suggest that lengthier commutes are only associated with lower satisfaction with amount of leisure. This finding is present among both men and women suggesting some level of trade-off between these activities, perhaps as other elements of work-time are considered less flexible. The impact of household time-use is also more relevant among women, particularly in respect to leisure. Provision of care, especially when extensive (20+ hours per week), has significant negative impacts on satisfaction with leisure for women, consistent with the perpetuation of their roles as primary care givers even within career households (Hardill, 2002; Garcia et al, 2011). Results pertaining to housework, somewhat counter-intuitively, are positive (although the results are not statistically significant 
for leisure). This may reflect that the act of performing housework, in itself, is not a source of dissatisfaction. Instead it is the impact of the uneven household division of labour, partly driven by partner working routines, which creates lower levels of satisfaction among those individuals, predominantly women, who perform the greatest amounts of housework.

\section{Conclusions}

This paper has explored time-use (working hours, overtime, housework, care, and commuting) and satisfaction levels among men and women in dual career households in a post-industrial economy, the UK. Specifically, the paper has sought to answer two research questions: (1) are distinctions present in time-use within dual career households in respect of gender, occupation, and employment sector, and; (2) how does the distribution of labour in dual career households impact satisfaction with (i) working hours, (ii) job overall, (iii) amount of leisure time, and (iv) use of leisure time? These questions have been explored empirically using the British Household Panel Survey (BHPS), 1993-2009, which allows for longitudinal exploration of patterns in time-use. Descriptive analysis has been developed using ordered probit analysis.

Analysis of the BHPS data suggests overall reductions in working hours during the sample period. Hours do remain long, though, in managerial and professional occupations especially in terms of hours of overtime. Work-time (hours including overtime) in certain occupation groups continues to exceed the UK WTR maximum. These trends are present among fulltime men in private sector managerial occupations, but also women, especially in professional occupations. The commute extends the time-use of men in particular. The descriptive analysis revealed that housework (including cleaning, ironing, shopping, cooking) and care (childcare and ill/elderly care) continue to fall predominantly upon women. These 
activities account for substantial combined time-use — up to 14 hours per week excluding caring for dependent children — and create difficulties in managing complex routines of paid employment with the household, effectively resulting in the 'double shift' (Jones, 2003: 7). Career women report lower satisfaction levels than their male counterparts. Given the relatively even distribution of work-time it is likely that this relative dissatisfaction is a result of the household division of labour. Ordered probit models were therefore used to investigate this apparent dissatisfaction. The regression analysis identifies the provision of care, occupation group, and partner employment characteristics as important drivers of dissatisfaction among full-time career women. Performing housework, in itself, is not a source of dissatisfaction. The results instead suggest the imposition of this work on women — as a result of partner working routines (especially extensive hours among men in managerial occupations) and gender norms in the household division of labour — reduces satisfaction as this increases the burden of housework and care. This is particularly pronounced among women exhibiting lengthy time-use, including public sector professionals. Interestingly, satisfaction levels among men appear linked with their own labour income and that of their partner, a finding not present among women. This may reflect financial compunction among men where dependent children are present. However, this could also represent a more mercenary attitude toward life. The findings also identify important occupation distinctions, especially in respect to the long hours worked by managers, and in contrast the extensive overtime reported by many professional women. Moreover there are sectoral differences, as satisfaction levels are greater in the public sector, possibly driven by greater availability of flexible working arrangements (see Wheatley, 2012). The analysis, thus, suggests that while work-time is increasingly comparable between career men and women, the impact of the household - the household division of labour driven in part by partner working routines - remains a particular burden on women's time-use and satisfaction 
levels. Evidence is indicative that the 'double shift' persists relative to household responsibilities. The descriptive analysis identified the potential impact of housework in constraining women's time available for paid work, preserving inequality among careerists. The distribution of household time, often, reflects the continuation of gender norms.

The findings presented in this paper have relevance to other post-industrial economies. A number of northern-EU countries are subject to the same/similar policies to those presented here i.e. EWTD. However certain cultural distinctions, as identified in Philp and Wheatley (2013), may reduce the 'closeness' of the UK findings in some respects. Countries including the US which continue to offer a more liberal stance on work-time and work-life balance policy may offer a closer fit, thus making these findings of greater significance in informing future political and social intervention. The approach undertaken is subject to some limitations including the generalizability of analysis using sample-survey panel data. In addition, more detailed data capturing the time spent performing different housework tasks (including but not limited to cleaning, ironing, shopping and cooking) would enhance the depth of the analysis provided. However, the BHPS data provides a year-on-year snapshot of the time-use and demographics of dual career households in the UK over an extended period. This would require substantial time and resources to collect using other methods.

This paper has presented important findings reflecting on the time-use and satisfaction levels of UK dual career households over 17 years, and has attempted to address an identified gap in knowledge relating to decision-making vis-à-vis the distribution of time-use in these households. The empirical findings presented in this paper extend previous research by considering the complex links between paid work, household labour, and realised outcomes for men and women in dual career households measured via stated satisfaction with various 
aspects of time-use and life overall. The findings are indicative of inequality diminishing in terms of paid employment but continuing in the household, overloading highly skilled women with incommensurately greater household responsibilities especially where male partners experience extensive work-time. The working lives of many women careerists thus continue to reflect significant constraint creating dissatisfaction and work-life conflict. However, the exact nature of the decisions, or constraints, which determine the distribution of time-use require further investigation. Further research would undoubtedly benefit from substantive qualitative elements to generate a more complete understanding of the complex interactions of partners in dual career households. Research is essential if positive change to intra-household decision-making and the household division of labour are to be realized.

\section{Acknowledgement}

The authors would like to thank the two anonymous referees for their comments on an earlier draft of this paper.

\section{References}

Angner, E. (2010). Subjective well-being. The Journal of Socio-Economics, 39(3), 361-368.

Arenius P., Kovalainen, A. (2006). Similarities and Differences Across the Factors Associated with Women’s Self-employment Preference in the Nordic Countries. International Small Business Journal, 24(31), 31-59.

Atkinson, C. and Hall, L. (2009). The Role of Gender in Varying Forms of Flexible Working. Gender, Work and Organization, 16(6), 650-666.

Baruch, Y. (2004). Transforming careers: from linear to multidirectional career paths - organizational and individual perspectives. Career Development International, 9(1), 58-73. 
Becker, G., (1976). The Economic approach to Human Behavior. Chicago: The University of Chicago Press.

BIS. (2011). Working Time Regulations: Statutory Instruments [online]. Available at: http://www.bis.gov.uk/.

BIS. (2011a). Flexible Working and Work-Life Balance [online]. Available at: http://www.bis.gov.uk/.

Blanchflower, D.G., Oswald. A.J. (2008). Is well-being U-shaped over the life cycle? Social Science \& Medicine, 66, 1733-49.

Bowles, H., McGinn, K. (2008). Untapped potential in the study of negotiation and gender inequality in organizations. Academy of Management Annals, 2, 99-132.

British Household Panel Survey [computer file], ESRC Research Centre on Micro-social Change. -Colchester: The Data Archive [distributor], 2009. Data files and associated documentation.

Brown, A., Charlwood, A., Spencer, D. (2012). Not all that it Might Seem: Why Job Satisfaction is Worth Studying despite it being a Poor Summary Measure of Job Quality. Work Employment \& Society, 26, 10071018.

Browning, M., Chiappori, P.A. (1998). Efficient Intra-Household Allocations: A General Characterization and Empirical Tests. Econometrica, 66(6), 1241-78.

Cha, Y. (2010). Reinforcing separate spheres: The effect of spousal overwork on men’s and women's employment in dual-earner households. American Sociological Review, 75(2), 303-9.

Crompton, R., Lewis, S., Lyonette, C., (2007). Continuities, change and transformations. In Cromption, R., Lewis, S., Lyonette, C. (Eds.), Women, Men, Work and Family in Europe. Palgrave Macmillian, New York.

Della Giusta, M., Jewell, S., Kambhampati, U. (2011). Gender and Life Satisfaction in the UK. Feminist Economics, 17(3), 1-34. 
Dolan, P., Peasgood, T., White, M. (2008). Do We Really Know What Makes Us Happy? A Review Of The Economic Literature On The Factors Associated With Subjective Wellbeing. Journal of Economic Psychology, 29(1), 94-122.

Ehrenreich, B., Ehrenreich, J. (1979). The professional-managerial class, in: P. Walker (Ed.). Between Labour and Capital. Boston: South End Press.

Ergeneli, A., Ilsev, A., (2010). Work-family Conflict and Job Satisfaction Relationship: The Roles of Gender and Interpretive Habits. Gender, Work and Organization, 17(6), 679-95.

Evetts, J. (2000). Analysing Change in Women’s Careers: Culture, Structure and Action Dimensions. Gender, Work and Organization, 7(1), 57-67.

Ford, J. Collinson, D. (2011). In search of the perfect manager? Work-life balance and managerial work. Work, Employment \& Society, 25(2), 257-73.

Garcia, I., Molina, H.A., Montuenga, V. (2011). Gender differences in childcare: Time allocation in five European countries. Feminist Economics, 17(1), 119-150.

Garcia, I., Molina, A., Navarro, M. (2007). How Satisfied are Spouses with their Leisure Time? Evidence from Europe. Journal of Family and Economic Issues, 28, 546-565.

Glass, J. (2004). Blessing or Curse: Work-Family Policies and Mother's Wage Growth over Time. Work and Occupations, 31(3), 367-394.

Goldthorpe, J. (1995). The service class revisited, in: T. Butler \&M. Savage (Eds). Social Change and the Middle Classes. London: UCL Press. 
Goos, M., Manning, A. (2007). Lousy and lovely jobs: the rising polarization of work in Britain. The Review of Economics and Statistics, 89(1), 118-33.

Gordon, D. (1996). Fat and Mean: The Corporate Squeeze of Working Americans and the Myth of Managerial Downsizing. New York: Martin Kessler.

Gregory, M., Connolly, S. (2008). The Price of Reconciliation: Part-Time Work, Families and Women’s Satisfaction. The Economic Journal, 118(526), F1-F7.

Grossbard, S. (2010). Independent Individual Decision-Makers in Household Models and the New Home Economics. IZA Discussion Paper No. 5138.

Hakim, C. (2002). Lifestyle Preferences as Determinants of Women’s Differentiated Labour Market Careers. Work and Occupations, 29(4), 428-459.

Hakim, C. (2004). Key issues in women's work: female diversity and the polarisation of women's employment. London: GlassHouse Press.

Hardill, I. (2002). Gender, Migration and the Dual Career Household. International Studies of Women and Place series. London: Routledge.

Hardill, I.,Watson, R. (2004). Career priorities within dual career households: An analysis of the impact of child rearing upon gender participation rates and earnings. Industrial Relations Journal, 35(1), 19-37.

Hardill, I., Wheatley, D. (2009). Dual-Career Couples, Gender and Migration. In Reuschke, D. (ed.) Wohnen und Gender: Theoretische, politische, soziale und räumliche Aspekte, 239-59, Wiesbaden: VS Verlag für Sozialwissenschaften.

Harris, L., Foster, C., Whysall, P. (2007). Maximising women's potential in the UK's retail sector. Employee Relations, 29(5), 492-505. 
Headey, B. (2008). Life goals matter to happiness: A revision of set-point theory. Social Indicators Research, 88(2), 213-231.

Hochschild, A., Machung, A. (1990). The Second Shift, Working Parents and The Revolution at Home. London: Piatkus.

Hodson, R (2005). Gender differences in job satisfaction: why aren’t women more dissatisfied? The Sociological Quarterly, 30(3), 385-399.

Jones, A. (2003). About Time for Change. June. London: The Work Foundation.

Lewis, J. (2001). The decline of the male breadwinner model: the implications for work and care. Social Politics, 8(2), 152-170.

Lewis, J., Campbell, M. (2008). What's in a Name? ‘Work and Family’ or 'Work and Life’ Balance Policies in the UK since 1997 and the Implications for the Pursuit of Gender Equality. Social Policy and Administration, 42(5), 524-541.

Livingston, B. (2011). Bargaining Behind the Scenes: Spousal Negotiation, Labor, and Work-Family Burnout. Journal of Management, December, 1-29, DOI: 10.1177/0149206311428355.

Lundberg, S., Pollak, R. (2007). The American Family and Family Economics. IZA Discussion Paper No. 2715.

MacDonald, M., Phipps, S., Lethbridge, L. (2005). Taking Its Toll: The Influence of Paid and Unpaid Work on Women's Well-Being. Feminist Economics, March, 11(1), 63-94.

McDowell, L., Perrons, D., Fagan, C., Ray, K., Ward, K. (2005). The contradictions and intersections of class and gender in a global city: placing working women's lives on the research agenda. Environment \& Planning A, 37(3), 441-61. 
Peel, S., Inkson, K. (2004). Contracting and careers: choosing between self-employment and organizational management. Career Development International, 9(6), 542-558.

Perrons, D., Fagan, C., McDowell, L., Ray, K., Ward, K. (2005). Work, Life and Time in the New Economy. Time and Society, 14(1), 51-64.

Philp, B., Wheatley, D. (2011). Time Scarcity and the Dual Career Household: Competing Perspectives. American Journal of Economics and Sociology, 70(3), 587-614.

Philp, B., Wheatley, D. (2013). European Work Time Regulation and Underemployment: A Quantitative Marxist Analysis. Economic Issues, 19(1), 57-74.

Sandow, E. (2014). Til Work Do Us Part: The Social Fallacy of Long-distance Commuting. Urban Studies, 51(3), 526-43.

Schwanen, T. (2007). Gender differences in Chauffeuring Children among Dual-Earner Families. The Professional Geographer, 59(4), 447-462.

Soobedar, Z. (2011). A semi-parametric analysis of the rising breadwinner role of women in the UK. Review of the Economics of the Household, 9(3), 415-28.

Stutzer, A., Frey, B. S. (2008). Stress that doesn’t Pay: The Commuting Paradox. Scandinavian Journal of Economics, 110(2), 339-366.

Sullivan, O. (2010). Changing Differences by Educational Attainment in Fathers’ Domestic Labour and Child Care. Sociology, 44(4), 716-733.

University of Essex. Institute for Social and Economic Research and National Centre for Social Research, Understanding Society: Wave 1, 2009-2010 and Wave 2, Year 1 (Interim Release), 2010 [computer file]. 3rd Edition. Colchester, Essex: UK Data Archive [distributor], February 2012. SN: 6614, http://dx.doi.org/10.5255/UKDA-SN-6614-3. 
van Hooff, J. (2011). Rationalising inequality: heterosexual couples' explanations and justifications for the division of housework along traditionally gendered lines. Journal of Gender Studies, 20(1), 19-30.

van Staveren, I. (2010). Post-Keynesianism meets feminist economics. Cambridge Journal of Economics, 34 (6), 1123-44.

Vermeulen, F. (2002). Collective Household Models: Principles and Main Results. Journal of Economic Surveys, 16, 533-64.

Wheatley, D. (2012). Work-life Balance, Travel-to-Work, and the Dual Career Household. Personnel Review, 41(6), 813-831.

Wheatley, D. (2013). Location, Vocation, Location? Spatial Entrapment among Women in Dual Career Households. Gender, Work and Organization, 20(6), 720-36.

Wheatley, D., Hardill, I., Philp, B. (2011). “Managing” Reductions in Working Hours: A Study of Work-Time and Leisure Preferences in UK Industry. Review of Political Economy, 23(3), 409-20.

Wight, V., Raley, S. (2009). When Home Becomes Work: Work and Family Time among Workers at Home. Social Indicators Research, 93(1), 197-202. 